\title{
Role of PPAR $\gamma$ in the nutritional and pharmacological actions of carotenoids
}

This article was published in the following Dove Press journal:

Research and Reports in Biochemistry

27 April 2016

Number of times this article has been viewed

\author{
Wen-en Zhao' \\ Guoqing Shi \\ Huihui $\mathrm{Gu}^{1,3}$ \\ Nguyen Ba Ngoc ${ }^{1,4}$ \\ 'School of Chemical Engineering \\ and Energy, Zhengzhou University, \\ ${ }^{2}$ School of Food and Bioengineering, \\ Zhengzhou University of Light \\ Industry, ${ }^{3}$ School of Life Sciences, \\ Zhengzhou University, Zhengzhou, \\ People's Republic of China; ${ }^{4}$ Faculty \\ of Food Industry, College of Food \\ Industry, Da Nang, Vietnam
}

\begin{abstract}
Peroxisome proliferator-activated receptor gamma (PPAR $\gamma$ ) has been shown to play an important role in the biological effects of carotenoids. The PPAR $\gamma$-signaling pathway is involved in the anticancer effects of carotenoids. Activation of PPAR $\gamma$ partly contributes to the growth-inhibitory effects of carotenoids ( $\beta$-carotene, astaxanthin, bixin, capsanthin, lutein, and lycopene) on breast cancer MCF7 cells, leukemia K562 cells, prostate cancer (LNCaP, DU145, and PC3 cells), and esophageal squamous cancer EC109 cells. PPAR $\gamma$ is the master regulator of adipocyte differentiation and adipogenesis. Downregulated PPAR $\gamma$ and PPAR $\gamma$-target genes have been associated with the suppressive effects of $\beta$-carotene and lycopene on 3T3L1 and $\mathrm{C} 3 \mathrm{H} 10 \mathrm{~T} 1 / 2$ adipocyte differentiation and adipogenesis. $\beta$-Carotene is cleaved centrally into retinaldehyde by $\mathrm{BCO} 1$, the encoding gene being a PPAR $\gamma$-target gene. Retinaldehyde can be oxidized to retinoic acid and also be reduced to retinol. $\beta$-Carotene can also be cleaved asymmetrically into $\beta$-apocarotenals and $\beta$-apocarotenones by $\mathrm{BCO} 2$. The inhibitory effects of $\beta$-carotene on the development of adiposity and lipid storage are dependent substantially on BCO1-mediated production of retinoids. The effects of $\beta$-carotene on body adiposity were absent in BCO1-knockout mice. Retinoid metabolism is connected with the activity of PPAR $\gamma$ in the control of body-fat reserves. Retinoic acid, retinaldehyde, retinol, and $\beta$-apocarotenals exert suppressive effects on preadipocyte differentiation and adipogenesis via downregulation of PPAR $\gamma$ expression in cell culture. The molecular mechanisms underlying retinoic acid effects on adipose-tissue biology and the development of adiposity remain poorly understood. Adiposity can be affected by retinoids through long-lasting effects at critical developmental stages. Retinol saturase increases PPAR $\gamma$-transcriptional activity and adipocyte differentiation. Other carotenoids that have been reported to suppress adipocyte differentiation and lipid accumulation in the main via modulation of PPAR $\gamma$ and PPAR $\gamma$-target genes include astaxanthin, bixin, norbixin, $\beta$-cryptoxanthin, fucoxanthin and its metabolites, lycopene, apo-10'-lycopenoic acid, siphonaxanthin, and neoxanthin, except paprika pigments. Lutein, lycopene, and paprika carotenoids reduce proinflammatory cytokine levels by an induction of PPAR $\gamma$ in immune tissues and cells. Lycopene, apo-10'-lycopenoic acid, and astaxanthin might prevent atherosclerosis through modifying cholesterol metabolism via increasing PPAR $\gamma$ expression in macrophages.
\end{abstract}

Keywords: carotenoids, PPAR $\gamma$, anti-cancer, anti-obesity, antiatherosclerosis

\section{Introduction}

PPAR $\gamma$, a member of the nuclear hormone-receptor superfamily, functions as a ligandactivated transcription factor. It participates in numerous physiological and pathological processes, such as lipid metabolism, adipocyte differentiation, insulin sensitivity, the growth of cells in various organs, and the occurrence of several human diseases,
Correspondence: Wen-en Zhao School of Chemical Engineering and Energy, Zhengzhou University, 100 Science Road, Zhengzhou, Henan 45000I, People's Republic of China Email zhaowenen@zzu.edu.cn
Research and Reports in Biochemistry 2016:6 I3-24

13

Dovepress

http://dx.doi.org/10.2147/RRBC.S83258 (c) (1) (5) 2016 hhao et al. This work is published and licensed by Dove Medical Press Limited. The full terms of this license are available at https://www.dovepress.com/terms.php cc) ${ }_{\mathrm{BY}} \mathrm{NC}$ and incorporate the Creative Commons Attribution - Non Commercial (unported, v3.0) License (http://(creativecommons.org/licenses/by-n/ 3.00 ). By accessing the work you hereby accept the Terms. Non-commercial uses of the work are permitted without any further permission from Dove Medical Press Limited, provided the work is properly attributed. For permission for commercial use of this work, please see paragraphs 4.2 and 5 of our Terms (https://www.dovepress.com/terms.php). 
including obesity, dyslipidemia, diabetes, inflammation, hypertension, atherosclerosis, and cancer. ${ }^{1-3}$ Endogenous PPAR $\gamma$ ligands include 15-deoxy- $\Delta^{12,14}$-prostaglandin $\mathrm{J}_{2}$ $\left(15 \mathrm{~d}-\mathrm{PGJ}_{2}\right)$, as well as linoleic, linolenic, and arachidonic acids. Pharmaceutical PPAR $\gamma$ ligands include the thiazolidinediones (ciglitazone, pioglitazone, rosiglitazone, and troglitazone), which are commonly prescribed medications for the treatment of type 2 diabetes mellitus. The PPAR $\gamma$ activated by ligands (also known as PPAR $\gamma$ agonists) forms a heterodimer with $\mathrm{RXR} \alpha$ and binds to its specific response elements, PPREs, in the promoter region of various target genes. Emerging information shows that PPAR $\gamma$ is expressed in many human tissues, such as breast, colon, lung, ovary, prostate, stomach, bladder, and thyroid, where it regulates cell proliferation, differentiation, and apoptosis. This property makes PPAR $\gamma$ an important target for the development of new and effective anticancer therapies. ${ }^{4,5}$ PPAR $\gamma$ has been shown to be involved in the important biological effects of carotenoids, such as growth and apoptosis of cancer cells, adipocyte differentiation and adipogenesis, inflammatory responses, and cholesterol metabolism in macrophages.

\section{PPAR $\gamma$ activation in carotenoid- inhibited cancer-cell proliferation}

A growing body of evidence indicates that carotenoids act as potent growth-inhibitory agents in several tumor cells, including breast, colon, prostate, lung, melanoma, and leukemia cells. ${ }^{6,7}$ The PPAR $\gamma$-signaling pathway has been shown to be involved in the anticancer effects of carotenoids. Sharoni et al proposed that some carotenoids, such as $\beta$-carotene, lycopene, phytoene, and phytofluene, caused the transactivation of PPREs in MCF7 cells cotransfected with PPAR $\gamma$. This activity was lower than that achieved with the known PPAR ligands, such as $15 \mathrm{~d}_{-} \mathrm{PGJ}_{2}$ and ciglitazone. ${ }^{8}$ Combined treatment of $3.8 \mu \mathrm{M}$ fucoxanthin, a carotenoid from the edible seaweed Undaria pinnatifida, with $10 \mu \mathrm{M}$ troglitazone (a PPAR $\gamma$ agonist) remarkably induced DNA fragmentation, which led to a reduction in viability of human $\mathrm{Caco} 2$ colon cancer cells, but fucoxanthin and troglitazone, individually, did not have significant effects on Caco2-cell viability. ${ }^{9}$ Lycopene at 10-25 $\mu \mathrm{M}$ showed no effects on the proliferation of prostate cancer PC3 cells. However, lycopene at $25 \mu \mathrm{M}$ augmented the antiproliferative effects of PPAR $\gamma$ agonists (15d-PGJ ${ }_{2}$, ciglitazone, and pioglitazone), modulated PPAR $\gamma$-induced apoptosis, and inhibited the expression of growth and survival-associated genes in PC3 cells. ${ }^{10}$ Effects of lutein on the proliferation of PC3 cells were similar to those of lycopene. Lutein induced a mild decrease in proliferation, improved PPAR $\gamma$ agonist- induced cell-cycle arrest and apoptosis, and altered the expression of growth and apoptosis-associated biomarker genes. ${ }^{11}$

Although these studies suggested the involvement of the PPAR $\gamma$ pathway, they did not investigate PPAR $\gamma$ directly or the contribution of the PPAR $\gamma$ pathway to the inhibition of cancer-cell growth by carotenoids. Recently, our experimental results showed that $\beta$-carotene enhanced the expression of PPAR $\gamma$ in breast cancer MCF7 cells. GW9662, an irreversible antagonist of PPAR $\gamma$, can partly attenuate the growth inhibition and apoptosis caused by $\beta$-carotene. In addition, $\beta$-carotene induced reactive oxygen species production and cytochrome $\mathrm{C}$ release. The results suggested that the synergistic effect of PPAR $\gamma$ expression and reactive oxygen species production may have accounted for $\beta$-carotene-mediated anticancer activities. ${ }^{12}$ Our other results demonstrated that pretreatment with GW9662 partly attenuated the inhibition of cell proliferation, apoptosis, and interference in cell-cycle progression induced by $\beta$-carotene, astaxanthin, capsanthin, and bixin in leukemia K562 cells. These carotenoids upregulated the expression of PPAR $\gamma$ and cyclin-dependent kinase inhibitor p21 and downregulated the expression of cyclin D1. ${ }^{13}$ Moreover, rosiglitazone augmented the inhibitory effects of carotenoids on K562-cell proliferation. Specific PPAR $\gamma$ inhibition by GW9662 and PPAR $\gamma$ small interfering RNA (siRNA) weakened cell-growth suppression by the carotenoid and rosiglitazone combination greatly. GW9662 attenuated the enhanced upregulation of PPAR $\gamma$ expression caused by the combination treatment. GW9662 and PPAR $\gamma$ siRNA also significantly attenuated the upregulation of p21 and downregulation of cyclin D1 caused by carotenoids and rosiglitazone. ${ }^{14}$ These data suggest that the PPAR $\gamma$-signaling pathway is involved in the suppression of tumor-cell proliferation by carotenoids. Carotenoids suppress the cell growth through activating PPAR $\gamma$, in turn via stimulating p21 and inhibiting cyclin D1. A similar role of PPAR $\gamma$ has been observed in the antiproliferative effects of $\beta$-carotene and lycopene on the human esophageal squamous cancer-cell line EC109 (Nguyen et al, unpublished).

Yang et al reported that lycopene treatment significantly inhibited the proliferation of androgen-dependent human prostate $\mathrm{LNCaP}$ cancer cells, increased the expression of PPAR $\gamma$ and LXR $\alpha$ at 24 and 48 hours, and decreased cellular total cholesterol levels and increased the expression of the ABCA1 and ApoA1 proteins at 96 hours. Incubation of LNCaP cells with lycopene in the presence of GW9662 and the LXR $\alpha$ antagonist GGPP restored cell proliferation to the control levels and significantly suppressed protein expression of PPAR $\gamma$ and $\mathrm{LXR} \alpha$, as well as increased cellular 
total cholesterol levels. LXR $\alpha$ knockdown by siRNA against LXR $\alpha$ significantly enhanced the proliferation of LNCaP cells, whereas siLXR $\alpha$ knockdown followed by incubation with lycopene restored the proliferation to the control level. The authors proposed that the antiproliferative effect of lycopene on LNCaP cells involved the activation of the PPAR $\gamma$-LXR $\alpha-$ ABCA1 pathway, leading to reduced cellular total cholesterol levels. ${ }^{15}$ They observed similar results in androgen-independent prostate cancer DU145 cells, and came to the same conclusion. ${ }^{16}$

It has been well known that PPAR $\gamma$ agonists have anticancer activity. ${ }^{17,18}$ Taking these aforementioned findings together, it is obvious that upregulation of PPAR $\gamma$ expression is associated with the antiproliferative effects of carotenoids on cancer cells. However, it remains unclear whether they have the capacity to function as PPAR $\gamma$ agonists and thus can inhibit the proliferation of cancer cells. The results tested using the PPAR $\gamma 2$ CALUX reporter cell line showed that the carotenoids violaxanthin, phytofluene, neurosporene, lycopene, $\beta$-carotene, $\gamma$-carotene, and $\delta$-carotene from extracts of tomato were able to induce PPAR $\gamma 2$-mediated luciferase expression. ${ }^{19}$ It appears that carotenoids might have some PPAR $\gamma$-agonist potential.

\section{Repression of PPAR $\gamma$ expression in the suppressive effects of carotenoids on adipocyte differentiation and adipogenesis $\beta$-Carotene and its metabolite retinoids (vitamin $\mathrm{A}$ and its derivatives)}

Obesity caused by excess accumulation of adipose tissue has become a medical problem worldwide, because it may increase the risk of various diseases, such as heart disease, type 2 diabetes, and obstructive sleep apnea. Adipose tissue mass is determined by processes governing adipocyte number and size. Proliferation and differentiation lead to increases in adipocyte number, and increasing storage of triacylglycerols causes the expansion of adipocyte size. Adipocyte differentiation is a complex process, in which a variety of transcription factors are involved. One of the early events is the upregulation of $\mathrm{C} / \mathrm{EBP} \beta$ expression. $\mathrm{C} / \mathrm{EBP} \beta$ then acts to upregulate the expression of adipogenic factors, such as $\mathrm{C} / \mathrm{EBP} \alpha$, which control the late stage of adipogenesis. PPAR $\gamma$ is considered the master regulator of adipogenesis, and in its absence adipocyte differentiation cannot proceed. ${ }^{20,21}$

The role of $\beta$-carotene in adipocyte biology has received more and more attention. The modulation of PPAR $\gamma$ has been reported to be associated with the inhibitory effects of $\beta$-carotene on adipocyte differentiation and adipogenesis. Kawada et al reported previously that $\beta$-carotene, $\beta$-apo8 '-carotenal, and retinal markedly suppressed the differentiation of 3T3L1 preadipocytes to adipocytes through RAR upregulation and suppression of PPAR $\gamma 2 .{ }^{22}$ Murine C3H10T1/2 adipocyte differentiation was conducted with rosiglitazone in the presence of $\beta$-carotene, (all- $E$ )-lycopene and other dietary constituents for 7 days. $\beta$-Carotene inhibited rosiglitazone-stimulated lipid formation and expression of the adipocyte-differentiation markers $\operatorname{PPAR} \gamma, \operatorname{PPAR} \alpha$, and $\mathrm{C} / \mathrm{EBP} \alpha$, and of genes related to lipid metabolism, such as $L P L, A P 2$, and $C P T 1 B$. (all-E)-lycopene showed moderate inhibition. The observed inhibitory effects of $\beta$-carotene correlated with the modulation of genes involved in adipocyte differentiation. ${ }^{23}$ However, it was observed that $\beta$-carotene treatment at a concentration of $20 \mu \mathrm{M}$ but not $10 \mu \mathrm{M}$ in 3T3L1 adipocytes during differentiation for 4 days enhanced the expression of genes related to insulin sensitivity, including adiponectin, $A L B P$, and GLUT4 (involved in glucose incorporation), $P P A R \gamma 1, P P A R \gamma 2, C / E B P \alpha$, and $C / E B P \beta$ in the medium. The expression of the $C / E B P \delta$ gene tended to be reduced. $\beta$-Carotene accumulation inhibited TNF $\alpha$-mediated reduction in the expression of these genes related to insulin sensitivity. ${ }^{24}$ It is very likely that the expression of $P P A R \gamma$ and other adipogenic and lipogenic genes is suppressed by carotenoid treatment at the early stage of adipocyte differentiation and stimulated at the late stage. In addition, a 9-cis $\beta$-carotene-enriched diet inhibited atherogenesis and fattyliver formation in low-density lipoprotein receptor-knockout mice. $^{25}$

Evidence from cell-culture and animal-model studies indicates that substantial actions of $\beta$-carotene in adipose tissue biology are mediated by its metabolites. $\beta$-Carotene is the natural precursor for apocarotenoid molecules, including retinoids (vitamin A and its derivatives, such as retinaldehyde [Rald] and retinoic acid [RA]). ${ }^{26}$ It is cleaved centrally into two molecules of Rald by BCO1, a cytosolic enzyme present in various tissues, including the intestine, liver, testes, and adipose tissue. ${ }^{27,28}$ Rald can be oxidized to RA and also be reduced to retinol. ${ }^{29} \beta$-Carotene can also undergo asymmetric cleavage to yield $\beta$-apocarotenals and $\beta$-apocarotenones by $\mathrm{BCO} 2$, which localizes to mitochondria. ${ }^{30,31} \mathrm{BCO} 1$ activity is robust in the intestine and liver. The $B C O 1$ gene has been shown to be transcriptionally regulated by the action of PPARs and RXRs in both mice and humans ${ }^{32,33}$ and also by feedback inhibition of RA. ${ }^{34}$ After $B C O 1$-knockout mice were fed with chow containing $\beta$-carotene as a major 
vitamin A precursor, vitamin A levels fell dramatically and the $\beta$-carotene accumulated in large quantities in several tissues examined. The mice developed dyslipidemia, such as fatty liver and elevated serum free fatty acids, and were more susceptible to high-fat diet-induced obesity compared to wild mice. The expression of PPAR $\gamma$-regulated genes also increased in fat depots. Therefore, BCO1 was identified as the key enzyme for vitamin A production. ${ }^{35}$ It was reported that BCO1 expression was induced during NIH3T3L1 adipocyte differentiation. $\beta$-Carotene but not all-trans-retinol decreased lipid content of mature adipocytes and was metabolized to RA in mature adipocytes. RA decreased the expression of PPAR $\gamma$ and $\mathrm{C} / \mathrm{EBP} \alpha$, and reduced the lipid content of mature adipocytes. Dietary $\beta$-carotene decreased PPAR $\gamma$ expression in white adipose tissue of vitamin A-deficient mice. However, $B C O 1$, as a PPAR $\gamma$-target gene, is highly expressed in mature adipocytes, allowing for $\beta$-carotene to be converted to RA. ${ }^{36}$ Recently, von Lintig et al reported that $\mathrm{BCO}$ knockout mice showed increased expression of $\mathrm{BCO} 2$ in adipocytes, and $\beta-10^{\prime}$-apocarotenol accumulated as the major $\beta$-carotene derivative. In wild-type mice, dietary $\beta$-carotene significantly reduced body adiposity (by $28 \%$ ), leptinemia, and adipocyte size, resulted in a general downregulation of gene expression in adipose tissue, and downregulated PPAR $\gamma$ and PPAR $\gamma$-target genes. These effects of $\beta$-carotene were absent in $B C O 1$-knockout mice despite $\beta$-10'-apocarotenoid production, demonstrating that these effects were dependent on the BCO1-mediated production of retinoids. The study showed clearly that $\beta$-carotene plays an important role in the control of body-fat reserves in mice and that BCO1 is a critical molecular player for the regulation of PPAR $\gamma$ activity in adipocytes. ${ }^{37} \mathrm{~A}$ study in human pulmonary alveolar epithelial cells showed that $\beta$-carotene downregulated BCO1 expression through suppression of PPAR $\gamma / \mathrm{RXR} \alpha$ binding to the BCO1 promoter, which decreased retinoid production. Systemic vitamin A insufficiency in the lung may be associated with an increase of lung cancer risk upon $\beta$-carotene supplementation in smokers. ${ }^{38}$ On the other hand, chronic alcohol intake was reported to decrease hepatic retinoid levels but increase messenger RNA (mRNA) concentrations of BCO1, BCO2, PPAR $\gamma, \operatorname{PPAR} \alpha$, and TR $\beta$ and upregulate protein levels of CMO2, PPAR $\gamma$, and PPAR $\alpha$ in Fischer 344 rats. $^{39}$

The importance of vitamin A and its derivatives, Rald and RA from $\beta$-carotene, in adipose tissue biology and the development of adiposity has received close attention in recent years. It has long been established that RA is an inhibitor of preadipocyte differentiation in cell culture. ${ }^{40-44}$ RA inhibits adipogenesis early in adipocyte differentiation by repressing $\mathrm{C} / \mathrm{EBP} \beta$-mediated transcription and decreasing PPAR $\gamma$ expression through binding to and activating RA receptors. ${ }^{45-48}$ RA can no longer prevent adipocyte differentiation if added to the cell culture after early differentiation is completed. ${ }^{36,49}$ Results from preadipocytes and mesenchymal stem cell models have shown that RA specifically blocks the occupancy of $\mathrm{C} / \mathrm{EBP} \beta$ of the $C E B P \alpha$ promoter and does not act directly on $\mathrm{C} / \mathrm{EBP} \beta$. RA stimulates the expression of the TGF $\beta$ effector protein Smad3, which can interact with $\mathrm{C} / \mathrm{EBP} \beta$ via its Mad homology 1 domain and can interfere with $\mathrm{C} / \mathrm{EBP} \beta$ DNA binding. In the absence of Smad3, RA is not able to inhibit adipocyte differentiation or to elicit a decrease in $\mathrm{C} / \mathrm{EBP} \beta$ DNA occupancy. The data suggest that $\mathrm{Smad} 3$ is required for the inhibition effects of RA on adipogenesis. ${ }^{50}$ RA inhibits pig preadipocyte differentiation, activating RAR and downregulating $\operatorname{PPAR} \gamma, \operatorname{RXR} \alpha$, and SREBP1C. ${ }^{45,51}$ Recently Berry and Noy reported that in mature adipocytes, RA activated both RARs and PPAR $\beta / \delta$, thereby enhancing lipolysis and depleting lipid stores. RA treatment of obese mice induced expression of PPAR $\beta / \delta$ and RAR-target genes involved in regulation of lipid homeostasis, leading to weight loss and improved insulin responsiveness. The results indicated that suppression of obesity and insulin resistance by RA was largely mediated by PPAR $\beta / \delta$ and further enhanced by activation of RARs. ${ }^{52}$ Berry et al also showed that RA inhibited adipocyte differentiation by activating the CRABP2-RAR $\gamma$ path in preadipose cells, thereby upregulating the expression of the adipogenesis inhibitors Pref1, Sox9, and KLF2, resulting in inhibition of the expression of the adipogenic proteins CEBP and PPAR $\gamma$ and SREBP1C. Therefore, they pointed out that RA suppresses adipogenesis in vivo. ${ }^{53}$ Interestingly, Dave et al reported that stem bromelain (SBM) inhibited adipogenesis irreversibly. SBM and all-trans-retinoic acid (atRA) treatment together inhibited adipocyte differentiation more effectively than either alone. SBM, together with atRA, may be a potent modulator of obesity by repressing the PPAR $\gamma$-regulated adipogenesis pathway at all stages and by augmenting TNF $\alpha$-induced lipolysis and apoptosis in mature adipocytes. ${ }^{54}$ In addition, Lee et al reported that RA inhibited BMP4-induced C3H10T1/2 mesenchymal stem cell adipogenic commitment and differentiation, as observed by reductions in key adipogenic genes/transcription factors (C/EBP $\alpha$, PPAR $\gamma, \mathrm{aP} 2)$, lipogenic genes (LPL, FAS, GLUT4), and lipid accumulation. RA significantly suppressed the BMP4-triggered phosphorylation of both Smad1/5/8 and p38MAPK. They suggested that RA inhibited the BMP4 
induction of $\mathrm{C} 3 \mathrm{H} 10 \mathrm{~T} 1 / 2$ adipocyte commitment via downregulating Smad/p38MAPK signaling. ${ }^{55}$

Although a growing body of evidence indicates that RA represses adipogenesis and reduces body-fat reserves in tissues, including brown adipose tissue, white adipose tissue (WAT), skeletal muscle, and the liver, ${ }^{56-59}$ controversial data have been reported, including retinoid effects on hepatic lipid and blood-lipid profile. ${ }^{60,61}$ García-Rojas et al indicated that 9-cis-RA and atRA are powerful agents for the promotion of bovine adipogenesis. The 9-cis-RA and atRA increased PGC $1 \alpha$ mRNA expression in bovine adipogenic cultures, with 9-cis-RA being a better activator. Expression of PPAR $\gamma$ mRNA was increased by $30 \mu \mathrm{M} \beta$-carotene, though $10 \mu \mathrm{M}$ $\beta$-carotene decreased expression compared with a differentiation medium. However, it is not conclusive that activation of the PPAR system contributes to the ability of carotenoids to promote adipose tissue differentiation. ${ }^{62}$

Another in vivo trial showed that PPAR $\gamma$ mRNA was significantly increased in rat adipose tissue by 13-cis-RA treatment. ${ }^{63}$ It was reported that adipogenesis in 3T3L1 preadipocytes was accompanied by RA production generated primarily by Aldh1a1. Aldh1 enzymes and RA regulated PPAR $\gamma$ expression by mechanisms involving ZnF423 expression. ${ }^{64}$ Villarroya et al held that the final effect of RA on preadipocyte differentiation depends on the concentration and isomer availability, as well as on the relative RAR and RXR availability in the cells. ${ }^{65}$ A new pathway of RA inhibition of adipocyte differentiation was proposed recently. Retinoylated CRM1 disrupts the export of MEK1 from the nucleus. Rich MEK1 in the nucleus decreases PPAR $\gamma$ availability and thus inhibits adipogenesis, while also disrupting the MEK1-ERK signaling cascade. ${ }^{66}$ This shows that the molecular mechanisms underlying RA effects on adipocyte differentiation and adipogenesis are complex and remain poorly understood. Furthermore, it is proposed that there is a high turnover of adipocytes at all adult ages in humans. Adiposity can be affected by retinoids throughout life, and particularly through long-lasting effects at critical developmental stages. ${ }^{59,67}$ The following experimental results are pertinent to this comment. In WAT of retinyl palmitate-fed young rats during the suckling period (day 21), which is a critical period in the development of adipose tissue, small adipocytes and proliferating cell nuclear antigen increased and expression of adipogenic markers (PPAR $\gamma$ and LPL) reduced. Vitamin A-treated rats fed a high-fat diet for 16 weeks after vitamin A being stopped developed higher adiposity gain (particularly subcutaneous fat) than control rats through mechanisms that may relate to changes in adipose tissue development, likely mediated by RA. ${ }^{68}$
Rald is also an inhibitor of adipogenesis. Ziouzenkova et al showed that Rald was present in rodent fat, inhibited PPAR $\gamma$-induced adipogenesis, and increased energy dissipation. In vivo, mice lacking the Rald-catabolizing enzyme Raldh1 resisted diet-induced obesity and insulin resistance. In vitro, Rald inhibited RXR and PPAR $\gamma$ activation. They identified Rald as a distinct transcriptional regulator of metabolic responses to a high-fat diet. ${ }^{69,70}$ It has been shown that Rald induced UCP1 levels in white adipocytes by selectively activating RAR, recruiting the coactivator PGC1 $\alpha$, and inducing UCP1-promoter activity. Raldh1 is expressed predominately in WAT, including visceral depots in mice and humans. Raldh1 and Rald have been established as the determinants of adipocyte plasticity and adaptive thermogenesis. ${ }^{71}$

Retinol is very hydrophobic, and normally sequestrated by RBPs. ${ }^{72}$ Intracellularly, CRBPs protect retinol from the cellular milieu and facilitate channeling of retinol toward specific enzymes required either for its oxidation to RA or for its esterification to retinyl esters. ${ }^{73-76}$ Three CRBPs CRBP1, CRBP2, and CRBP3 - have been identified in murine tissues. ${ }^{73,75,77}$ It was reported that CRBP1 was a cytosolic protein specifically expressed in preadipocytes in adipose tissue that regulated adipocyte differentiation, in part by affecting PPAR $\gamma$ activity. CRBP1 deficiency led to significantly enhanced adipocyte differentiation and increased intracellular triglyceride accumulation, due to augmented PPAR $\gamma$ activity. ${ }^{78} \mathrm{CRBP} 3$ is present in adipocytes and a direct target of PPAR $\gamma$ activation. It is expressed during mid- and late-stage differentiation of adipocytes. The lack of CRBP3 is associated with decreased adipose tissue development and markedly downregulated PPAR $\gamma$ activity. The function of CRBP3 is to facilitate the esterification of retinol to retinyl ester in the mammary gland during lactation. ${ }^{17,79,80}$ It is well established that CRBP2 is expressed primarily in the small intestine and binds both retinol and Rald in the enterocyte. CRBP2 mediates intracellular retinoid transport and metabolism. ${ }^{81}$ The effect of vitamin A deficiency on obesity might increase the risk of fat deposition and also the risk of chronic inflammation associated with obesity. ${ }^{82}$ However, a synergistic effect of dietary lipids and retinol on the growth of adipose tissue was observed in young (3 weeks old) rats. Cafeteria diets enriched in retinol (excess vitamin A) increased adiposity due to increased adipocyte hypertrophy, which was concomitant with a lower expression of RAR $\alpha$ and RAR $\gamma$ mRNA and a higher expression of PPAR $\gamma$ in subcutaneous WAT and in isolated mature adipocytes. The adipocyte precursors from subcutaneous WAT had higher proliferation and differentiation capacities. ${ }^{83}$ It 
has been reported that $\beta$-carotene given orally was readily absorbed intact and partially metabolized by suckling rats, as indicated by intact $\beta$-carotene in serum and the liver and increased RA-mediated transcriptional responses in the intestine and liver. Responses in WAT were dependent on retinyl palmitate supplementation. The WAT of $\beta$-carotenesupplemented rats was enriched in larger adipocytes with enhanced adipogenic markers (PPAR $\gamma$ and downstream genes) and reduced markers of proliferative status (proliferating cell nuclear antigen) compared to the WAT of vitamin A-supplemented rats. ${ }^{84}$ It is evident that vitamin A supplementation with $\beta$-carotene or retinyl palmitate in early life may affect adipose tissue development differentially.

Retinol saturase (RetSat), an enzyme catalyzing the saturation of all-trans-retinol to produce $(R)$-all-trans-13,14dihydroretinol, is proposed to play an important role in the biology of adipocytes. It is induced during adipocyte differentiation of 3T3L1 cells and by PPAR $\gamma$ activation. PPAR $\gamma$ is required for RetSat expression in mature adipocytes. Schupp et al showed that RetSat was required for adipocyte differentiation in the 3T3L1 cell-culture model. In adipose tissue, RetSat was expressed in adipocytes but downregulated in obesity, most likely owing to infiltration of macrophages that repressed RetSat expression. RetSat increased PPAR $\gamma$ transcriptional activity and adipocyte differentiation, depending on its intact FAD/NAD dinucleotide-binding motif. However, RetSat was not required for adipogenesis when 3T3L1 cells were provided with pioglitazone. Thiazolidinedione treatment reversed low RetSat expression in the adipose tissue of obese mice.$^{85}$ Moise et al reported that RetSat-null mice maintained on either low-fat or high-fat diets gained weight and accumulated more fat. This increased adiposity was associated with upregulation of PPAR $\gamma$ and also its downstream target: FABP4/AP2. They proposed that dihydroretinoids produced by RetSat control physiological processes that influence PPAR $\gamma$ activity and regulate lipid accumulation in mice. ${ }^{86}$

$\beta$-Apocarotenals resulting from asymmetric cleavage of $\beta$-carotene, such as $\beta$-apo- 8 '-carotenal and especially $\beta$-apo-14'-carotenal, inhibit PPAR $\gamma$ and PPAR $\alpha$ responses. During adipocyte differentiation, $\beta$-apo-14'-carotenal inhibits PPAR $\gamma$-target gene expression and adipogenesis..$^{22,87}$ $\beta$-Apo-13-carotenone was reported to upregulate expression of the adipocyte marker genes $L P L, A P 2$, adiponectin, and $P P A R \gamma$ in 3T3L1 cells. $\beta$-Apo-10'-carotenoic acid increased expression of LPL and AP2, but did not have a significant influence on expression levels of adiponectin or PPAR $\gamma{ }^{88}$ $\beta$-Apo-14'-carotenal, $\beta$-apo-14'-carotenoic acid, and $\beta$-apo13 -carotenone were demonstrated to be RAR antagonists in transactivation assays. ${ }^{89}$ However, $\beta$-apo-13-carotenone and $\beta$-apo-10'-carotenoic acid lack RAR-antagonist activity. They failed to diminish the inhibitory effects of a relatively large dose of exogenous all-trans-RA on adipocyte differentiation. ${ }^{88}$

It is evident that $\beta$-carotene has a complex influence on PPAR $\gamma$-regulated pathways controlling adipogenesis. An adipose tissue-specific conversion of $\beta$-carotene via carotenoid oxygenases can influence the activities of key transcription factors. Moreover, different differentiation stages and different organ resources of adipocytes may contribute to changeable consequences of $\beta$-carotene derivatives. $\beta$-Carotene could suppress PPAR $\gamma$ expression and activity and decrease lipid content in mature adipocytes, mainly through being metabolized to their derivatives (retinoids and apocarotenoids). Carotenoid derivatives could regulate the expression of direct target genes by serving as ligands of the PPAR and/or the RXR moiety of permissive PPAR:RXR heterodimers, which help control adipogenesis and adipocyte metabolism.

\section{Other carotenoids}

In addition to $\beta$-carotene, other carotenoids also display antiobesity effects, in the main via downregulation of PPAR $\gamma$ expression. Astaxanthin has been shown to inhibit increases in body weight and weight of adipose tissue induced by a high-fat diet, reduce liver and plasma triglycerides and total cholesterol in mice,,$^{90}$ and promote size reduction in visceral adipocytes, with a remarkable decrease in free fatty acid and a significant increase in blood high-density lipoprotein (HDL)-cholesterol concentrations in Otsuka Long-Evans Tokushima fatty rats. ${ }^{91}$ It was found that astaxanthin was able to selectively bind PPAR $\gamma$, but unable to activate transcription of PPAR $\gamma$ reporters. Astaxanthin inhibited rosiglitazone-induced adipogenesis of 3T3L1 cells by antagonizing PPAR $\gamma$ transcriptional activity. ${ }^{92}$ The reportergene assay and ligand-binding domain studies showed that astaxanthin activated PPAR $\alpha$ but inhibited PPAR $\gamma$ transactivation activity, and had no effect on PPAR $\delta / \beta$ activation. It reduced lipid accumulation and cellular cholesterol and triglyceride concentrations by rewiring the transcriptome in lipid-loaded HepG2 hepatocytes. ${ }^{93}$ However, astaxanthin improved the adipogenic differentiation potential of mouse neural progenitor cells. Astaxanthin-treated neural progenitor cells showed prominent fat formation and induced significant overexpression of adipogenesis-related AP and PPAR $\gamma$ mRNA. ${ }^{94}$ This may relate to lipid metabolism in different organs. 
Takahashi et al reported that in 3T3L1 adipocytes and HepG2 hepatocytes, the treatment of such isoprenols as farnesol and geranylgeraniol caused the transactivation of the PPAR $\gamma$-reporter gene and increased expression of AP2 in 3T3L1 adipocytes. It can be seen in their Figure 2 that, except zeaxanthin, astaxanthin, $\beta$-carotene, $\beta$-cryptoxanthin, and lycopene at $100 \mu \mathrm{M}$, a concentration hardly achievable in aqueous solutions, induced PPAR $\gamma$ transactivation. ${ }^{95} \mathrm{~A}$ determination of PPAR $\gamma$ activity in monkey CV1 kidney cells by reporter assay showed that astaxanthin, bixin, and lycopene had the potential to activate PPAR $\gamma$ as novel ligands. ${ }^{96}$

Bixin and norbixin (annatto extracts) activated PPAR $\gamma$ and induced mRNA expression of PPAR $\gamma$-target genes, such as $A P 2, L P L$, and adiponectin, in differentiated 3T3L1 adipocytes and enhanced insulin-dependent glucose uptake. ${ }^{97}$ Bixin and norbixin activated PPAR $\alpha$-transactivation activity and induced the mRNA expression of PPAR $\alpha$-target genes involved in fatty acid oxidation in PPAR $\alpha$-expressing HepG2 hepatocytes. In obese KK-Ay mice, bixin suppressed hyperlipidemia development and hepatic lipid accumulation and increased the mRNA levels of PPAR $\alpha$-target genes related to fatty acid oxidation in the livers. Moreover, bixin also improved obesity-induced dysfunctions of carbohydrate metabolism..$^{98}$

Tsuchida et al reported that the oral intake of $\beta$-cryptoxanthin exerted anti-obesity effects by lowering visceral fat levels. ${ }^{99}$ Anti-obesity effects of $\beta$-cryptoxanthin have also been reported in an obese mouse model. ${ }^{100}$ $\beta$-Cryptoxanthin inhibited lipid accumulation in 3T3L1 cells, affected cell differentiation through its function as a ligand of RAR $\alpha$ and RAR $\gamma$, and downregulated mRNA expression of PPAR $\gamma$. Their results indicated that $\beta$-cryptoxanthin inhibited 3T3L1 adipogenesis via the downregulation of PPAR $\gamma$ through RAR activation. ${ }^{101}$

Fucoxanthin is a major carotenoid present in edible seaweed, such as Undaria pinnatifida and Hizikia fusiformis. Fucoxanthin and its metabolites, fucoxanthinol and amarouciaxanthin A, inhibited the adipocyte differentiation of 3T3L1 cells through downregulation of PPAR $\gamma$ and $\mathrm{C} / \mathrm{EBP} \alpha{ }^{102-104}$ Interestingly, Kang et al reported that fucoxanthin from the edible brown seaweed Petalonia binghamiae promoted 3T3L1 adipocyte differentiation, increased triglyceride accumulation, and increased protein levels of PPAR $\gamma, \mathrm{C} / \mathrm{EBP} \alpha$, SREBP1C, and AP2, and adiponectin mRNA level during the early stage of differentiation (days $0-2)$. However, it reduced the expression of PPAR $\gamma, \mathrm{C} / \mathrm{EBP} \alpha$, and SREBP1C during the intermediate (days 2-4) and late stages (days 4-7) of differentiation. Their results suggest that fucoxanthin exerts differing effects on 3T3L1 cells of different differentiation stages. ${ }^{105}$ Xanthigen (brown marine algae fucoxanthin + pomegranate-seed oil) was reported to suppress adipocyte differentiation and lipid accumulation in adipocytes and markedly downregulate the protein levels of PPAR $\gamma, \mathrm{C} / \mathrm{EBP} \beta$, and $\mathrm{C} / \mathrm{EBP} \delta$, as well as a key enzyme involved in adipogenesis - FAS. It also upregulated NAD ${ }^{+}$ dependent histone deacetylases (Sirt1) and activated AMPK signaling in differentiated 3T3L1 adipocytes. ${ }^{106}$ Xanthigen promoted weight loss and reduced body and liver fat in obese women. ${ }^{107}$

Several studies has shown that lycopene has an impact on adipose tissue biology. It was reported that a higher intake of lycopene was associated with a smaller waist circumference and lower visceral and subcutaneous fat mass. ${ }^{108}$ Lycopene is beneficial in protecting against high-fat diet-induced fatty liver. Dietary lycopene downregulated BCO1, $\operatorname{PPAR} \gamma$, and FABP3 mRNA expression in rat kidney and adrenal glands. Lycopene may play an important role in the modulation of $\beta$-carotene, retinoid, and/or lipid metabolism. ${ }^{109}$ Lycopene increased plasma concentration of adiponectin and upregulated mRNA expressions of adiponectin, Sirt1 (a nicotine adenine dinucleotide-dependent protein deacetylase), (FoxO1, a transcriptional factor involved in the regulation of adipocyte differentiation), and FAT/CD36, but downregulated PPAR $\gamma$ in the adipose tissue of obese rats. ${ }^{110}$ Apo-10'lycopenoic acid (APO10LA), a potential oxidation product of apo-10'-lycopenal generated endogenously by $\mathrm{BCO} 2$ cleavage of lycopene, modulated the transcriptome of 3T3L1 adipocytes in a manner similar to atRA. It activated RAR and impacted the transcription of RAR-target genes, downregulating leptin, $\mathrm{CEBP} \alpha$, and $\mathrm{RXR} \alpha$ and upregulating PPAR $\alpha$ expression, but showed no effect on adipogenesis, PPAR $\gamma$, or adiponectin mRNA-expression levels in 3T3L1 cells. ${ }^{111}$ APO10LA protected against the development of steatosis in $o b / o b$ mice by upregulating SIRT1 gene expression and activity. It decreased acetylated FoxO1 protein levels and the mRNA level of acetyl-CoA carboxylase $1 .{ }^{112}$ Lycopene and APO10LA inhibited high-saturated-fat diet-induced steatosis in $\mathrm{BCO} 2-\mathrm{knockout}$ male mice through differential mechanisms. Lycopene or APO10LA reduced hepatic total cholesterol and activated Sirt1 signaling, which resulted in reduced fatty acids and triglyceride-synthesis markers and elevated cholesterol-efflux genes. Steatosis inhibition by lycopene induced PPAR $\alpha$ - and PPAR $\gamma$-related genes in mesenteric adipose tissue and increased mesenteric adipose tissue fatty acid utilization. Female mice did not develop steatosis. ${ }^{113}$ Tomato and lycopene feeding decreased lipid 
uptake, hepatic triglyceride concentrations, and PPAR $\gamma$ expression in both male wild-type and $\mathrm{Bco}^{-/}{ }^{-}$mice. ${ }^{114} \mathrm{It}$ seems that the effects of lycopene are not dependent on the products cleaved by $\mathrm{BCO} 2$.

Paprika pigments containing large amounts of capsanthin and capsorubin were shown to promote 3T3L1 adipocyte differentiation and upregulate PPAR $\gamma$ mRNA and protein expression, as well as adiponectin mRNA expression and secretion. ${ }^{15}$ The green algal carotenoid siphonaxanthin was found to suppress adipocyte differentiation and lipid accumulation in 3T3L1 cells. The effects of siphonaxanthin were largely limited to the early stages of adipogenesis. After 8 days of adipocyte differentiation, siphonaxanthin decreased the gene expression of $\mathrm{C} / \mathrm{EBP} \alpha, \operatorname{PPAR} \gamma, \mathrm{FABP} 4$, and $\mathrm{Scd} 1$. Siphonaxanthin administration reduced the total weight of WAT, especially the mesenteric WAT in KK-Ay mice, and enhanced fatty acid oxidation in adipose tissue. ${ }^{116}$

Okada et al ${ }^{117}$ tested the suppressive effects of 13 naturally occurring carotenoids (lutein, violaxanthin, $\alpha$-carotene, $\beta$-carotene 5,6-epoxide, canthaxanthin, citranaxanthin, rhodoxanthin, $\beta$-cryptoxanthin, antheraxanthin, lutein epoxide, neoxanthin, and capsorubin) on 3T3L1 adipocyte differentiation. They demonstrated that neoxanthin reduced intracellular lipid accumulation and the expression of $\mathrm{C} /$ $\mathrm{EBP} \alpha$ and PPAR $\gamma$ mRNAs without affecting the expression of $\mathrm{C} / \mathrm{EBP} \beta$ or $\mathrm{C} / \mathrm{EBP} \gamma \mathrm{mRNAs}$. The other 12 carotenoids used did not show suppressive effects on adipose-cell differentiation. Combined with their results on fucoxanthin and fucoxanthinol, they suggested that carotenoids containing an allene bond and an additional hydroxyl substituent on the side group may show suppressive effects on adipocyte differentiation in 3T3L1 cells. ${ }^{102-104,117}$ It should be noted that their observation is not in agreement with the results obtained by Shirakura et al using $\beta$-cryptoxanthin ${ }^{101}$ or García-Rojas et al using lutein in a bovine adipocyte-differentiation system, in which $30 \mu \mathrm{M}$ lutein increased PPAR $\gamma \mathrm{mRNA}$ expression. ${ }^{62}$ Perhaps the hydroxyl group at the third position of the ionone ring is also important for carotenoid effects. Moreover, carotenoid metabolism in adipose tissues has not yet been understood adequately. It is thus unclear whether the intact molecules of carotenoids or their derivatives exert suppressive effects on adipogenesis and PPAR $\gamma$ activity.

\section{PPAR $\gamma$ in anti-inflammatory actions and modification of cholesterol metabolism by carotenoids}

PPAR $\gamma$ is known to be involved in governing inflammatory response, particularly in macrophages. It may play a role in anti-inflammatory actions by interfering with proinflammatory transcription factors. ${ }^{118}$ Immune-cell macrophages induced by lipopolysaccharide (LPS) produce nitric oxide using iNOS. iNOS is an important enzyme that mediates inflammatory processes. Improper upregulation of iNOS is associated with pathophysiology of certain types of human cancers, as well as inflammatory disorders, including atherosclerosis. ${ }^{119}$ It is well known that PPAR and RXR regulate immune function, including repression of NFKB signaling and inflammatory cytokine production. ${ }^{120}$ The anti-inflammatory effects of carotenoids have been found to be associated with the suppression of proinflammatory transcription factors through increasing PPAR $\gamma$ levels. Selvaraj et al reported that lutein may play a role in LPS-induced inflammatory responses. Dietary lutein and fat interacted to modify nitrite production in LPS-stimulated macrophages. High levels of lutein increased nitrite production; however, high levels of fat reversed the stimulatory effect of lutein. ${ }^{121}$ They also reported that lutein and dietary fat or eicosapentaenoic acid interact to modulate iNOS mRNA levels through the PPAR $\gamma$-RXR pathway in LPS-stimulated chickens and HD11 cell lines. Increasing lutein with high fat $(6 \%)$ or eicosapentaenoic acid (15 mmol/L) increased PPAR $\gamma$ and RXR $\alpha$ mRNA levels. Lutein increased PPAR $\alpha$ mRNA levels in both macrophages and HD11 cells and RXR $\gamma$ mRNA levels in macrophages. GW9662 and LG101208, an RXR antagonist, prevented lutein-induced iNOS mRNA regulation. ${ }^{122}$ The effect of dietary lutein or polyunsaturated fatty acid (PUFA) fat on lutein and lipid content and PPAR and RXR expression in chicken immune tissues during inflammation was investigated to assess the modification of in vivo inflammatory responses by dietary PUFA fat and lutein. ${ }^{123}$ Lutein in immune tissues was depleted during inflammation, and the depletion extent was dependent on dietary lutein levels. ${ }^{124}$ Similarly, fat levels were modified during inflammation. ${ }^{125}$ Selvaraj et al showed that LPS injection decreased the lutein content and increased the fat content in chicken liver and spleen. Dietary PUFA fat at $6 \%$ ameliorated the lutein-depletion effect of LPS. Dietary lutein and PUFA fat content modulated liver and spleen PPAR $\gamma / \alpha$ and RXR $\gamma / \alpha$ isomers during the proinflammatory response to LPS. High dietary lutein or high PUFA fat increased all PPAR- and RXR-isomer mRNA levels. Therefore dietary lutein and PUFA fat were anti-inflammatory, due to modification of immune tissue lutein content, PPAR and RXR isomers, and IL-1 $\beta$ mRNA levels in the liver and spleen, mainly due to modification of immune responses to LPS stimulation. ${ }^{123}$ Apo-10'-lycopenoic acid exerts anti-inflammatory effects in 
adipose tissue and adipocytes. It reduces the production of the proinflammatory markers IL-6 and IL-1 $\beta$ with upregulation of PPAR $\alpha$ expression and without effect on PPAR $\gamma$ expression. ${ }^{111}$ Paprika carotenoids have also been suggested to be useful for suppressing the enhanced inflammatory response of adipose tissue. Adipocytokine from adipocyte cells has been known to be related to chronic inflammation in adipocyte cells in obesity. Paprika pigments suppressed mRNA expression of IL-6, MCP1, resistin, and TNF $\alpha$, as well as NO production in a coculture of 3T3L1 adipocytes and RAW264.7 macrophage system. ${ }^{115}$

Hypercholesterolemia is one of the most important risk factors for atherosclerosis, in which macrophages play a central role. The accumulation of cholesterol-loaded macrophages in the arterial wall is the key event of the early atherosclerotic lesion. Cholesterol efflux from macrophages, which is mediated by ABCA1 and ABCG1, is thought to be a major process involved in plaque regression when hypercholesterolemia is reversed. ${ }^{126,127}$ Astaxanthin was shown to promote ABCA1 and ABCG1 expression in various macrophages and to have little effect on PPAR $\gamma, \mathrm{LXR} \alpha$, or LXR $\beta$. Astaxanthin enhanced apoA-I/HDL-mediated cholesterol efflux from RAW264.7. It is proposed that the potential cardioprotective properties of astaxanthin might be associated with an enhanced antiatherogenic function of HDL. ${ }^{128}$ In addition, astaxanthin was reported to reduce total cholesterol in mice and the cellular cholesterol in HepG2 hepatocytes and increase HDL-cholesterol concentrations in rats. ${ }^{90,91,93}$ As mentioned earlier, lycopene increased the expression of PPAR $\gamma, \mathrm{LXR} \alpha$, and ABCA1 and decreased cellular total cholesterol levels in human prostate LNCaP and DU145 cancer cells. ${ }^{15,16}$ Lycopene or APO10LA reduced hepatic total cholesterol and elevated cholesterol-efflux genes in BCO2-knockout male mice. ${ }^{113}$ It appears that lycopene, apo-10'-lycopenoic acid, and astaxanthin may act as antiatherosclerotic nutrients through modifying cholesterol metabolism. $\beta$-Cryptoxanthin was also found to induce ABCA1 and ABCG1 mRNAs and ABCA1 protein in macrophages. ${ }^{129}$ It is also helpful for cholesterol efflux.

\section{Summary}

As the roles of carotenoids in relation to health and disease have become progressively understood, molecular mechanisms mediating the effects of carotenoids have received growing attention. In addition to their antioxidant activity, carotenoids may exert their beneficial effects via another way: transcriptional modulation of the important gene expression concerned. As an important transcription factor, PPAR $\gamma$ has been proven to be involved in antiproliferation, antiadiposity, anti-inflammation, and cholesterol-homeostasis modulation of carotenoids, as reviewed in this paper. Carotenoids, as well as their products and metabolites, can regulate the expression of direct target genes by serving as ligands of the PPAR and/or the RXR moiety of permissive PPAR:RXR heterodimers or by indirect mechanisms. Furthermore, in recent years new research has emerged, pointing to new molecular pathways, including PPAR $\gamma$ functioning, by which carotenoids and their derivatives exert extensive beneficial effects. Ongoing studies will offer new insights into their biological activities and molecular mechanisms, and thereby contribute to improved dietary or supplementation-based strategies and future therapeutic interventions using PPAR $\gamma$ as a potential target.

\section{Disclosure}

The authors report no conflicts of interest in this work.

\section{References}

1. Lehrke M, Lazar MA. The many faces of PPAR $\gamma$. Cell. 2005;123: 993-999.

2. Feige JN, Gelman L, Michalik L, Desvergne B, Wahli W. From molecular action to physiological outputs: peroxisome proliferator-activated receptors are nuclear receptors at the crossroads of key cellular functions. Prog Lipid Res. 2006;45:120-159.

3. Semple RK, Chatterjee VK, O'Rahilly S. PPAR $\gamma$ and human metabolic disease. J Clin Invest. 2006;116:581-589.

4. Han S, Roman J. Peroxisome proliferator-activated receptor $\gamma$ : a novel target for cancer therapeutics? Anticancer Drugs. 2007;18: 237-244.

5. Ondrey F. Peroxisome proliferator-activated receptor $\gamma$ pathway targeting in carcinogenesis: implications for chemoprevention. Clin Cancer Res. 2009;15:2-8.

6. Gallicchio L, Boyd K, Matanoski G, et al. Carotenoids and the risk of developing lung cancer: a systematic review. Am J Clin Nutr. 2008;88:372-383.

7. Nishino H, Murakoshi M, Tokuda H, Satomi Y. Cancer prevention by carotenoids. Arch Biochem Biophys. 2009;483:165-168.

8. Sharoni Y, Danilenko M, Dubi N, Ben-Dor A, Levy J. Carotenoids and transcription. Arch Biochem Biophys. 2004;430:89-96.

9. Hosokawa M, Kudo M, Maeda H, Kohno H, Tanaka T, Miyashita K. Fucoxanthin induces apoptosis and enhances the antiproliferative effect of the PPAR $\gamma$ ligand, troglitazone, on colon cancer cells. Biochim -Biophys Acta. 2004;1675:113-119.

10. Rafi MM, Kanakasabai S, Reyes MD, Bright JJ. Lycopene modulates growth and survival associated genes in prostate cancer. J Nutr Biochem. 2013;24:1724-1734.

11. Rafi MM, Kanakasabai S, Gokarn SV, Bright JJ. Dietary lutein modulates growth and survival genes in prostate cancer cells. J Med Food. 2015;18:173-181.

12. Cui Y, Lu Z, Bai L, Shi Z, Zhao W, Zhao B. $\beta$-Carotene induces apoptosis and up-regulates peroxisome proliferator-activated receptor $\gamma$ expression and reactive oxygen species production in MCF-7 cancer cells. Eur $J$ Cancer. 2007;43:2590-2601.

13. Zhang X, Zhao W, Hu L, Zhao L, Huang J. Carotenoids inhibit proliferation and regulate expression of peroxisome proliferatorsactivated receptor gamma (PPAR $\gamma$ ) in K562 cancer cells. Arch Biochem Biophys. 2011;512:96-106. 
14. Zhao H, Gu H, Zhang H, Li J, Zhao W. PPAR $\gamma$-dependent pathway in the growth-inhibitory effects of K562 cells by carotenoids in combination with rosiglitazone. Biochim Biophys Acta. 2014;1840:545-555.

15. Yang CM, Lu IH, Chen HY, Hu ML. Lycopene inhibits the proliferation of androgen-dependent human prostate tumor cells through activation of PPAR $\gamma$-LXR $\alpha$-ABCA1 pathway. J Nutr Biochem. 2012;23:8-17.

16. Yang CM, Lu IH, Chen HY, Hu ML. Lycopene and the LXR $\alpha$ agonist T0901317 synergistically inhibit the proliferation of androgenindependent prostate cancer cells via the PPAR $\gamma$-LXR $\alpha$-ABCA1 pathway. J Nutr Biochem. 2012;23:1155-1162.

17. Sainis I, Vareli K, Karavasilis, Briasoulis E. PPAR $\gamma$ : the portrait of a target ally to cancer chemopreventive agents. PPAR Res. 2008; 2008:436489.

18. Han SW, Roman J. Anticancer actions of PPAR $\gamma$ ligands: current state and future perspectives in human lung cancer. World J Biol Chem. 2010;1:31-40.

19. Gijsbers L, van Eekelen HD, de Haan LH, et al. Induction of peroxisome proliferator-activated receptor $\gamma$ (PPAR $\gamma$ )-mediated gene expression by tomato (Solanum lycopersicum L.) extracts. J Agric Food Chem. 2013;61:3419-3427.

20. Rosen ED, MacDougald OA. Adipocyte differentiation from the inside out. Nat Rev Mol Cell Biol. 2006;7:885-896.

21. Frey SK, Vogel S. Vitamin A metabolism and adipose tissue biology. Nutrients. 2011;3:27-39.

22. Kawada T, Kamei Y, Fujita A, et al. Carotenoids and retinoids as suppressors on adipocyte differentiation via nuclear receptors. Biofactors. 2000;13:103-109.

23. Warnke I, Goralczyk R, Fuhrer E, Schwager J. Dietary constituents reduce lipid accumulation in murine $\mathrm{C} 3 \mathrm{H} 10 \mathrm{~T} 1 / 2$ adipocytes: a novel fluorescent method to quantify fat droplets. Nutr Metab (Lond). 2011;8:30

24. Kameji H, Mochizuki K, Miyoshi N, Goda T. $\beta$-Carotene accumulation in 3T3-L1 adipocytes inhibits the elevation of reactive oxygen species and the suppression of genes related to insulin sensitivity induced by tumor necrosis factor- $\alpha$. Nutrition. 2010;26:1151-1156.

25. Harari A, Harats D, Marko D, Shaish A. A 9-cis $\beta$-carotene-enriched diet inhibits atherogenesis and fatty liver formation in LDL receptor knockout mice. J Nutr. 2008;138:1923-1930.

26. von Lintig J. Colors with functions: elucidating the biochemical and molecular basis of carotenoid metabolism. Annu Rev Nutr. 2010;30:35-56.

27. Paik J, During A, Harrison EH, Mendelsohn CL, Lai K, Blaner WS. Expression and characterization of a murine enzyme able to cleave $\beta$-carotene: the formation of retinoids. J Biol Chem. 2001;276:32160-32168.

28. Redmond TM, Gentleman S, Duncan T, Cunningham FX. Identification, expression, and substrate specificity of a mammalian $\beta$-carotene 15,15'-dioxygenase. J Biol Chem. 2001;276:6560-6565.

29. Duester G, Mic FA, Molotkov A. Cytosolic retinoid dehydrogenases govern ubiquitous metabolism of retinol to retinaldehyde followed by tissue-specific metabolism to retinoic acid. Chem Biol Interact. 2003;143-144:201-210.

30. Kiefer C, Hessel S, Lampert JM, et al. Identification and characterization of a mammalian enzyme catalyzing the asymmetric oxidative cleavage of provitamin A. J Biol Chem. 2001;276:14110-14116.

31. Lobo GP, Amengual J, Palczewski G, Babino D, von Lintig J. Mammalian carotenoid-oxygenases: key players for carotenoid function and homeostasis. Biochim Biophys Acta. 2012;1821:78-87.

32. Boulanger A, McLemore P, Copeland NG, et al. Identification of $\beta$-carotene- $15,15^{\prime}$-monooxygenase as a peroxisome proliferatoractivated receptor target gene. FASEB J. 2003;17:1304-1306.

33. Gong X, Tsai SW, Yan B, Rubin LP. Cooperation between MEF2 and PPAR $\gamma$ in human intestinal $\beta, \beta$-carotene $15,15^{\prime}$-monooxygenase gene expression. BMC Mol Biol. 2006;7:7.

34. Bachmann H, Desbarats A, Pattison P, et al. Feedback regulation of $\beta, \beta$-carotene $15,15^{\prime}$-monooxygenase by retinoic acid in rats and chickens. J Nutr. 2002;132:3616-3622.
35. Hessel S, Eichinger A, Isken A, Wyss A. CMO1 deficiency abolishes vitamin A production from $\beta$-carotene and alters lipid metabolism in mice. J Biol Chem. 2007;282:33553-33561.

36. Lobo GP, Amengua J, Li HN, et al. $\beta, \beta$-Carotene decreases peroxisome proliferator receptor gamma activity and reduces lipid storage capacity of adipocytes in a $\beta, \beta$-carotene oxygenase 1-dependent manner. $J$ Biol Chem. 2010;285:27891-27899.

37. Amengual J, Gouranton E, van Helden YG, et al. $\beta$-Carotene reduces body adiposity of mice via BCMO1. PLoS One. 2011;6:e20644.

38. Gong X, Marisiddaiah R, Rubin LP. $\beta$-Carotene regulates expression of $\beta$-carotene $15,15^{\prime}$-monoxygenase in human alveolar epithelial cells. Arch Biochem Biophys. 2013;539:230-238.

39. Luvizotto RA, Nascimento AF, Veeramachaneni S, Liu C, Wang XD. Chronic alcohol intake upregulates hepatic expression of carotenoid cleavage enzymes and PPAR in rats. J Nutr. 2010;140:1808-1814.

40. Sato M, Hiragun A, Mitsui H. Preadipocytes possess cellular retinoid binding proteins and their differentiation is inhibited by retinoids. Biochem Biophys Res Commun. 1980;95:1839-1845.

41. Murray T, Russell TR. Inhibition of adipose conversion in 3T3-L2 cells by retinoic acid. J Supramol Struct. 1980;14:255-266.

42. Kuri-Harcuch W. Differentiation of 3T3-F442A cells into adipocytes is inhibited by retinoic acid. Differentiation. 1982;23:164-169.

43. Castro-Munozledo F, Marsch-Moreno M, Beltran-Langarica A, KuriHarcuch W. Commitment of adipocyte differentiation in 3T3 cells is inhibited by retinoic acid, and the expression of lipogenic enzymes is modulated through cytoskeleton stabilization. Differentiation. 1987;36:211-219.

44. Stone RL, Bernlohr DA. The molecular basis for inhibition of adipose conversion of murine 3T3-L1 cells by retinoic acid. Differentiation. 1990;45:119-127.

45. Suryawan A, Hu CY. Effect of retinoic acid on differentiation of cultured pig preadipocytes. J Anim Sci. 1997;75:112-117.

46. Schwarz EJ, Reginato MJ, Shao D, Krakow SL, Lazar M A. Retinoic acid blocks adipogenesis by inhibiting $\mathrm{C} / \mathrm{EBP} \beta$-mediated transcription. Mol Cell Biol. 1997;17:1552-1561.

47. Ribot J, Felipe F, Bonet ML, Palou A. Changes of adiposity in response to vitamin A status correlate with changes of PPAR $\gamma 2$ expression. Obes Res. 2001;9:500-509.

48. Moon HS, Guo DD, Song HH, et al. Regulation of adipocyte differentiation by PEGylated all-trans retinoic acid: reduced cytotoxicity and attenuated lipid accumulation. J Nutr Biochem. 2007;18: 322-331.

49. Xue JC, Schwarz EJ, Chawla A, Lazar MA. Distinct stages in adipogenesis revealed by retinoid inhibition of differentiation after induction of PPAR . Mol Cell Biol. 1996;16:1567-1575.

50. Marchildon F, St-Louis C, Akter R, Roodman V, Wiper-Bergeron NL. Transcription factor $\mathrm{Smad} 3$ is required for the inhibition of adipogenesis by retinoic acid. J Biol Chem. 2010;285:13274-13284.

51. Brandebourg TD, Hu CY. Regulation of differentiating pig preadipocytes by retinoic acid. J Anim Sci. 2005;83:98-107.

52. Berry DC, Noy N. All-trans-retinoic acid represses obesity and insulin resistance by activating both peroxisome proliferation-activated receptor $\beta / \delta$ and retinoic acid receptor. Mol Cell Biol. 2009;29:3286-3296.

53. Berry DC, DeSantis D, Soltanian H, Croniger CM, Noy N. Retinoic acid upregulates preadipocyte genes to block adipogenesis and suppress diet-induced obesity. Diabetes. 2012;61:1112-1121.

54. Dave S, Kaur NJ, Nanduri R, Dkhar HK, Kumar A, Gupta P. Inhibition of adipogenesis and induction of apoptosis and lipolysis by stem bromelain in 3T3-L1 adipocytes. PLoS One. 2012;7:e30831.

55. Lee JS, Park JH, Kwon IK, Lim JY. Retinoic acid inhibits BMP4induced C3H10T1/2 stem cell commitment to adipocyte via downregulating Smad/p38MAPK signaling. Biochem Biophys Res Commun. 2011;409:550-555.

56. Bonet ML, Oliver J, Pico C, et al. Opposite effects of feeding a vitamin A-deficient diet and retinoic acid treatment on brown adipose tissue uncoupling protein 1 (UCP1), UCP2 and leptin expression. J Endocrinol. 2000;166:511-517. 
57. Mercader J, Ribot J, Murano I, et al. Remodeling of white adipose tissue after retinoic acid administration in mice. Endocrinology. 2006;147:5325-5332.

58. Amengual J, Ribot J, Bonet ML, Palou A. Retinoic acid treatment increases lipid oxidation capacity in skeletal muscle of mice. Obesity (Silver Spring). 2008;16:585-591.

59. Bonet ML, Ribot J, Palou A. Lipid metabolism in mammalian tissues and its control by retinoic acid. Biochim Biophys Acta 2012;1821:177-189.

60. Safonova I, Darimont C, Amri EZ, et al. Retinoids are positive effectors of adipose cell differentiation. Mol Cell Endocrinol. 1994;104: 201-211.

61. Bost F, Caron L, Marchetti I, Dani C, Le Marchand-Brustel Y, Binetruy B. Retinoic acid activation of the ERK pathway is required for embryonic stem cell commitment into the adipocyte lineage. Biochem J. 2002;361:621-627.

62. García-Rojas P, Antaramian A, Gonzalez-Davalos L, et al. Induction of peroxisomal proliferator-activated receptor $\gamma$ and peroxisomal proliferator-activated receptor $\gamma$ coactivator 1 by unsaturated fatty acids, retinoic acid, and carotenoids in preadipocytes obtained from bovine white adipose tissue. J Anim Sci. 2010;88:1801-1808.

63. Krskova-Tybitanclova K, Macejova D, Brtko J, Baculikova M, Krizanova O, Zorad S. Short term 13-cis-retinoic acid treatment at therapeutic doses elevates expression of leptin, GLUT4, PPAR $\gamma$ and aP2 in rat adipose tissue. J Physiol Pharmacol. 2008;59:731-743.

64. Reichert B, Yasmeen R, Jeyakumar SM, et al. Concerted action of aldehyde dehydrogenases influences depot-specific fat formation. Mol Endocrinol. 2011;25:799-809.

65. Villarroya F, Giralt M, Iglesias R. Retinoids and adipose tissues: metabolism, cell differentiation and gene expression. Int $J$ Obes. 1999;23:1-6.

66. Dave S, Nanduri R, Dkhar HK, Bhagyaraj E, Rao A, Gupta P. Nuclear MEK1 sequesters PPAR $\gamma$ and bisects MEK1/ERK signaling: a noncanonical pathway of retinoic acid inhibition of adipocyte differentiation. PLoS One. 2014;9:e100862.

67. Spalding KL, Arner E, Westermark PO, et al. Dynamics of fat cell turnover in humans. Nature. 2008;453:783-787.

68. Granados N, Amengual J, Ribot J, et al. Vitamin A supplementation in early life affects later response to an obesogenic diet in rats. Int J Obes. 2013;37:1169-1176.

69. Ziouzenkova O, Orasanu G, Sharlach M, et al. Retinaldehyde represses adipogenesis and diet-induced obesity. Nat Med. 2007;13: 695-702.

70. Ziouzenkova O, Plutzky J. Retinoid metabolism and nuclear receptor responses: new insights into coordinated regulation of the PPAR-RXR complex. FEBS Lett. 2008;582:32-38.

71. Kiefer FW, Vernochet C, O’Brien P, et al. Retinaldehyde dehydrogenase 1 regulates a thermogenic program in white adipose tissue. Nat Med. 2012;18:918-925.

72. Szuts EZ, Harosi FI. Solubility of retinoids in water. Arch Biochem Biophys. 1991;287:297-304.

73. Noy N. Retinoid-binding proteins: mediators of retinoid action. Biochem J. 2000;348:481-495.

74. Blaner WS, Piantedosi R, Sykes A, Vogel S. Retinoic acid synthesis and metabolism. In: Nau H, Blaner WS, editors. Retinoids: The Biochemical and Molecular Basis of Vitamin A and Retinoid Action. Berlin: SpringerVerlag; 1999:117-149.

75. Ong DE, Newcomer ME, Chytil F. Cellular retinoid-binding proteins. In Sporn MB, Roberts AB, Goodman DS, editors. Retinoids: Biology, Chemistry, and Medicine. 2nd ed. New York: Raven Press; 1994:283-317.

76. Napoli JL. A gene knockout corroborates the integral function of cellular retinol-binding protein in retinoid metabolism. Nutr Rev. 2000;58:230-236.

77. Vogel S, Mendelsohn CL, Mertz J, et al. Characterization of a new member of the fatty acid-binding protein family that binds all-transretinol. J Biol Chem. 2001;276:1353-1360.
78. Zizola CF, Frey SK, Jitngarmkusol S, Kadereit B, Yan N, Vogel S. Cellular retinol-binding protein type I (CRBP-I) regulates adipogenesis. Mol Cell Biol. 2010;30:3412-3420.

79. Zizola CF, Schwartz GJ, Vogel S. Cellular retinol-binding protein type III is a PPAR $\gamma$ target gene and plays a role in lipid metabolism. Am J Physiol Endocrinol Metab. 2008;295:E1358-E1368.

80. Piantedosi R, Ghyselinck N, Blaner WS, Vogel S. Cellular retinolbinding protein type III is needed for retinoid incorporation into milk. J Biol Chem. 2005;280:24286-24292.

81. E X, Zhang L, Lu J, et al. Increased neonatal mortality in mice lacking cellular retinol-binding protein II. J Biol Chem. 2002;277: 36617-36623.

82. Garcia OP. Effect of vitamin A deficiency on the immune response in obesity. Proc Nutr Soc. 2012;71:290-297.

83. Redonnet A, Ferrand C, Bairras C, et al. Synergic effect of vitamin A and high-fat diet in adipose tissue development and nuclear receptor expression in young rats. Br J Nutr. 2008;100:722-730.

84. Musinovic H, Bonet ML, Granados N, et al. $\beta$-Carotene during the suckling period is absorbed intact and induces retinoic acid dependent responses similar to preformed vitamin A in intestine and liver, but not adipose tissue of young rats. Mol Nutr Food Res. 2014;58:2157-2165.

85. Schupp M, Lefterova MI, Janke J, et al. Retinol saturase promotes adipogenesis and is downregulated in obesity. Proc Natl Acad Sci USA. 2009; 106:1105-1110.

86. Moise AR, Lobo GP, Erokwu B, et al. Increased adiposity in the retinol saturase-knockout mouse. FASEB J. 2010;24:1261-1270.

87. Ziouzenkova O, Orasanu G, Sukhova G, et al. Asymmetric cleavage of $\beta$-carotene yields a transcriptional repressor of retinoid $\mathrm{X}$ receptor and peroxisome proliferator-activated receptor responses. Mol Endocrinol. 2007;21:77-88.

88. Wang C, Jiang H, Yuen JJ, et al. Actions of $\beta$-apo-carotenoids in differentiating cells: differential effects in P19 cells and 3T3-L1 adipocytes. Arch Biochem Biophys. 2015;572:2-10.

89. Eroglu A, Hruszkewycz DP, dela Sena C, et al. Naturally occurring eccentric cleavage products of provitamin A $\beta$-carotene function as antagonists of retinoic acid receptors. J Biol Chem. 2012;287: $15886-15895$

90. Ikeuchi M, Koyama T, Takahashi J, Yazawa K. Effects of astaxanthin in obese mice fed a high-fat diet. Biosci Biotechnol Biochem. 2007; 71:893-899.

91. Kimura M, Iida M, Yamauchi H, et al. Astaxanthin supplementation effects on adipocyte size and lipid profile in OLETF rats with hyperphagia and visceral fat accumulation. J Funct Food. 2014;11:114-120.

92. Inoue $\mathrm{M}$, Tanabe $\mathrm{H}$, Matsumoto $\mathrm{A}$, et al. Astaxanthin functions differently as a selective peroxisome proliferator-activated receptor $\gamma$ modulator in adipocytes and macrophages. Biochem Pharmacol. 2012;84:692-700

93. Jia Y, Kim JY, Jun HJ, et al. The natural carotenoid astaxanthin, a PPAR- $\alpha$ agonist and PPAR- $\gamma$ antagonist, reduces hepatic lipid accumulation by rewiring the transcriptome in lipid-loaded hepatocytes. Mol Nutr Food Res. 2012;56:878-888.

94. Kim JH, Nam SW, Kim BW, Kim WJ, Choi YH. Astaxanthin improves the proliferative capacity as well as the osteogenic and adipogenic differentiation potential in neural stem cells. Food Chem Toxicol. 2010;48:1741-1745.

95. Takahashi N, Kawada T, Goto T, et al. Dual action of isoprenols from herbal medicines on both PPAR $\gamma$ and PPAR $\alpha$ in 3T3-L1 adipocytes and HepG2 hepatocytes. FEBS Lett. 2002;514:315-322.

96. Goto T, Takahashi N, Hirai S, Kawada T. Various terpenoids derived from herbal and dietary plants function as PPAR modulators and regulate carbohydrate and lipid metabolism. PPAR Res. 2010;2010:483958.

97. Takahashi N, Goto T, Taimatsu A, et al. Bixin regulates mRNA expression involved in adipogenesis and enhances insulin sensitivity in 3T3-L1 adipocytes through PPAR $\gamma$. Biochem Biophys Res Commun. 2009;390:1372-1376. 
98. Goto T, Takahashi N, Kato S, et al. Bixin activates PPAR $\alpha$ and improves obesity-induced abnormalities of carbohydrate and lipid metabolism in mice. J Agric Food Chem. 2012;60:11952-11958.

99. Tsuchida T, Mukai K, Mizuno Y, Masuko K, Minagawa K. The comparative study of $\beta$-cryptoxanthin derived from satsuma mandarin for fat of human body. Jpn Pharmacol Ther. 2008;36:247-253.

100. Takayanagi K, Morimoto S, Shirakura Y, et al. Mechanism of visceral fat reduction in Tsumura Suzuki obese, diabetes (TSOD) mice orally administered $\beta$-cryptoxanthin from satsuma mandarin oranges (Citrus unshiu Marc). J Agric Food Chem. 2011;59:12342-12351.

101. Shirakura Y, Takayanagi K, Mukai K, Tanabe H, Inoue M. $\beta$-Cryptoxanthin suppresses the adipogenesis of 3T3-L1 cells via RAR activation. J Nutr Sci Vitaminol. 2011;57:426-431.

102. Maeda H, Hosokawa M, Sashima T, Funayama K, Miyashita K. Fucoxanthin from edible seaweed Undaria pinnatifida, shows antiobesity effect through UCP1 expression in white adipose tissues. Biochem Biophys Res Commun. 2005;332:392-397.

103. Maeda H, Hosokawa M, Sashima T, Takahashi N, Kawada T, Miyashita K. Fucoxanthin and its metabolite, fucoxanthinol, suppress adipocyte differentiation in 3T3-L1 cells. Int J Mol Med. 2006;18: 147-152.

104. Yim MJ, Hosokawa M, Mizushina Y, Yoshida H, Saito Y, Miyashita K. Suppressive effects of amarouciaxanthin A on 3T3-L1 adipocyte differentiation through down-regulation of PPAR $\gamma$ and $\mathrm{C} / \mathrm{EBP} \alpha$ mRNA expression. J Agric Food Chem. 2011;59:1646-1652.

105. Kang SI, Ko HC, Shin HS, et al. Fucoxanthin exerts differing effects on 3T3-L1 cells according to differentiation stage and inhibits glucose uptake in mature adipocytes. Biochem Biophys Res Commun. 2011;409:769-774.

106. Lai CS, Tsai ML, Badmaev V, Jimenez M, Ho CT, Pan MH. Xanthigen suppresses preadipocyte differentiation and adipogenesis through down-regulation of PPAR $\gamma$ and C/EBPs and modulation of SIRT-1, AMPK, and FoxO pathways. J Agric Food Chem. 2012;60:1094-1101

107. Abidov M, Ramazanov Z, Seifulla R, Grachev S. The effects of Xanthigen $^{\mathrm{TM}}$ in the weight management of obese premenopausal women with non-alcoholic fatty liver disease and normal liver fat. Diabetes Obes Metab. 2010;12:72-81.

108. Sluijs I, Beulens JW, Grobbee DE, van der Schouw YT. Dietary carotenoid intake is associated with lower prevalence of metabolic syndrome in middle-aged and elderly men. J Nutr. 2009;139: 987-992.

109. Zaripheh S, Nara TY, Nakamura MT, Erdman JW. Dietary lycopene downregulates carotenoid 15,15'-monooxygenase and PPAR $\gamma$ in selected rat tissues. $J$ Nutr. 2006;136:4 932-938.

110. Luvizotto RA, Nascimento AF, Miranda NC, Wang XD, Ferreira AL. Lycopene-rich tomato oleoresin modulates plasma adiponectin concentration and mRNA levels of adiponectin, SIRT1, and FoxO1 in adipose tissue of obese rats. Hum Exp Toxicol. 2015;34: 612-619.

111. Gouranton E, Aydemir G, Reynaud E, et al. Apo-10'-lycopenoic acid impacts adipose tissue biology via the retinoic acid receptors. Biochim Biophys Acta. 2011;1811:1105-1114.

112. Chung J, Koo K, Lian F, Hu KQ, Ernst H, Wang XD. Apo-10'lycopenoic acid, a lycopene metabolite, increases sirtuin 1 mRNA and protein levels and decreases hepatic fat accumulation in ob/ob mice. J Nutr. 2012;142:405-410.

Research and Reports in Biochemistry

\section{Publish your work in this journal}

Research and Reports in Biochemistry is an international, peer-reviewed, open access journal publishing original research, reports, reviews and commentaries on all areas of biochemistry. The manuscript management system is completely online and includes a very quick and fair
113. Blanche CI, Liu, C, Lichtenstein AH, von Lintig J, Wang XD. Lycopene and apo-10'-lycopenoic acid have differential mechanisms of protection against hepatic steatosis in $\beta$-carotene- $9^{\prime}, 10^{\prime}$-oxygenase knockout male mice. J Nutr. 2015;145:268-276.

114. Tan HL, Moran NE, Cichon MJ, et al. $\beta$-Carotene- $9^{\prime}, 10^{\prime}$-oxygenase status modulates the impact of dietary tomato and lycopene on hepatic nuclear receptor-, stress-, and metabolism-related gene expression in mice. J Nutr. 2014;144:431-439.

115. Maeda H, Saito S, Nakamura N, Maoka T. Paprika pigments attenuate obesity-induced inflammation in 3T3-L1 adipocytes. ISRN Inflamm. 2013;2013:763758.

116. Li ZS, Noda K, Fujita E, Manabe Y, Hirata T, Sugawara T. The green algal carotenoid siphonaxanthin inhibits adipogenesis in 3T3-L1 preadipocytes and the accumulation of lipids in white adipose tissue of KK-Ay mice. J Nutr. 2015;145:490-498.

117. Okada T, Nakai M, Maeda H, Hosokawa M, Sashima T, Miyashita K. Suppressive effect of neoxanthin on the differentiation of 3T3-L1 adipose cells. J Oleo Sci. 2008;57:345-351.

118. Ricote M, Li AC, Willson TM, Kelly CJ, Glass CK. The peroxisome proliferator-activated receptor- $\gamma$ is a negative regulator of macrophage activation. Nature. 1998;391:79-82.

119. Surh YJ, Chun KS, Cha HH, et al. Molecular mechanisms underlying chemopreventive activities of anti-inflammatory phytochemicals: down-regulation of COX-2 and iNOS through suppression of NF- $\mathrm{KB}$ activation. Mutat Res. 2001;480-481:243-268.

120. Debril MB, Renaud JP, Fajas L, Auwerx J. The pleiotropic functions of peroxisome proliferator-activated receptor $\gamma$. J Mol Med (Berl). 2001;79:30-47.

121. Selvaraj RK, Koutsos EA, Calvert CC, Klasing KC. Dietary lutein and fat interact to modify macrophage properties in chicks hatched from carotenoid depleted or repleted eggs. J Anim Physiol Anim Nutr. 2005;90:70-80.

122. Selvaraj RK, Klasing KC. Lutein and eicosapentaenoic acid interact to modify iNOS mRNA levels through the PPAR $\gamma / \mathrm{RXR}$ pathway in chickens and HD11 cell lines. J Nutr. 2006;136:1610-1616.

123. Selvaraj RK, Shanmugasundaram R, Klasing KC. Effects of dietary lutein and PUFA on PPAR and RXR isomer expression in chickens during an inflammatory response. Comp Biochem Physiol A Mol Integr Physiol. 2010;157:198-203.

124. Koutsos EA, Calvert CC, Klasing KC. The effect of an acute phase response on tissue carotenoid levels of growing chickens (Gallus gallus domesticus). Comp Biochem Physiol A Mol Integr Physiol. 2003;135:635-646.

125. Contreras-Shannon V, Ochoa O, Reyes-Reyna SM, et al. Fat accumulation with altered inflammation and regeneration in skeletal muscle of CCR2 ${ }^{-/-}$mice following ischemic injury. Am J Physiol Cell Physiol. 2007;292:C953-C967.

126. Shibata N, Glass CK. Regulation of macrophage function in inflammation and atherosclerosis. J Lipid Res. 2009;50:S277-S281.

127. Oram JF. ATP-binding cassette transporter A1 and cholesterol trafficking. Curr Opin Lipidol. 2002;13:373-381.

128. Iizuka M, Ayaori M, Uto-Kondo H, et al. Astaxanthin enhances ATP-binding cassette transporter A1/G1 expressions and cholesterol efflux from macrophages. J Nutr Sci Vitaminol. 2012;58:96-104.

129. Matsumoto A, Mizukami H, Mizuno S, et al. $\beta$-Cryptoxanthin, a novel natural RAR ligand, induces ATP-binding cassette transporters in macrophages. Biochem Pharmacol. 2007;74:256-264.

\section{Dovepress}

peer-review system. Visit http://www.dovepress.com/testimonials.php to read real quotes from published authors. 